\title{
Vascular Repair and Regeneration as a Therapeutic Target for Pulmonary Arterial Hypertension
}

\author{
Laszlo Farkas ${ }^{\mathrm{a}}$ Martin Kolb ${ }^{\mathrm{b}}$ \\ ${ }^{\text {a }}$ Division of Pulmonary Disease and Critical Care Medicine, Department of Internal Medicine, Victoria Johnson \\ Center for Obstructive Lung Disease, Virginia Commonwealth University, Richmond, Va., USA; ${ }^{\mathrm{b}}$ Division of \\ Respirology, Department of Medicine, Firestone Institute for Respiratory Health, McMaster University, St. Joseph's \\ Healthcare, Hamilton, Ont., Canada
}

\section{Key Words}

Progenitor cells · Pulmonary arterial hypertension · Stem cells · Vascular regeneration

\begin{abstract}
The last decade has seen substantial changes in our understanding of the pathobiology of pulmonary arterial hypertension (PAH), a severe and devastating disease without curative treatment. It is now accepted that injury to the endothelial cells of the pulmonary arteries is central for the subsequent development of lumen-obliterative lung vascular lesions. A variety of circulating and lung-resident progenitor and stem cells likely contribute to vascular integrity, and evidence for the presence of cells expressing stem and progenitor cell markers is found inside and in the immediate vicinity of pulmonary vascular lesions in PAH. The currently available vasodilator therapies mainly target enhanced vasoconstriction in the lung circulation and help to maintain or improve right ventricular function, but do not treat pulmonary vascular remodeling, the underlying cause of the disease. Vascular gene therapy and cell therapy with progenitor and stem cells is a progressing field in the context of the development of novel treatment options for $\mathrm{PAH}$, but the majority of the studies are currently performed at the level of
\end{abstract}

preclinical studies in animal models. The current review provides an overview of the current knowledge on cell- and gene therapy-based approaches for vascular repair and regeneration in PAH.

Copyright $\odot 2013$ S. Karger AG, Basel

\section{Introduction}

Pulmonary arterial hypertension $(\mathrm{PAH})$ is a severe progressive disease of the pulmonary vasculature characterized by the obliteration of precapillary pulmonary arterioles, which leads to right heart failure and death [1]. The classification and subtypes of pulmonary hypertension $(\mathrm{PH})$ have been summarized in the results of the last

Previous articles in this series: 1. Bouros D, Laurent G: Regenerative medicine and stem cells: Prometheus revisited. Respiration 2013;85:1-2. 2. Kolios G, Moodley Y: Introduction to stem cells and regenerative medicine. Respiration 2013;85:3-10. 3. Ardhanareeswaran K, Mirotsou M: Lung stem and progenitor cells. Respiration 2013;85:89-95. 4. Tzouvelekis A, Ntolios P, Bouros D: Stem cell treatment for chronic lung diseases. Respiration 2013;85:179192. 5. Cárdenes N, Cáceres E, Romagnoli M, Rojas M: Mesenchymal stem cells: a promising therapy for the acute respiratory distress syndrome. Respiration 2013;85:267-278.

\section{KARGER}

E-Mail karger@karger.com www.karger.com/res
(C) 2013 S. Karger AG, Basel

$0025-7931 / 13 / 0855-0355 \$ 38.00 / 0$
Laszlo Farkas, MD, Victoria Johnson Center for Obstructive Lung Disease Division of Pulmonary Disease and Critical Care Medicine, Department of Internal Medicine, Virginia Commonwealth University, Molecular Medicine Research Building, 6th Floor, Room 6054, 1200 East Broad Street

Richmond, VA 23298-0456 (USA), E-Mail lfarkas@ @cu.edu, laszlo.farkas75@gmail.com 


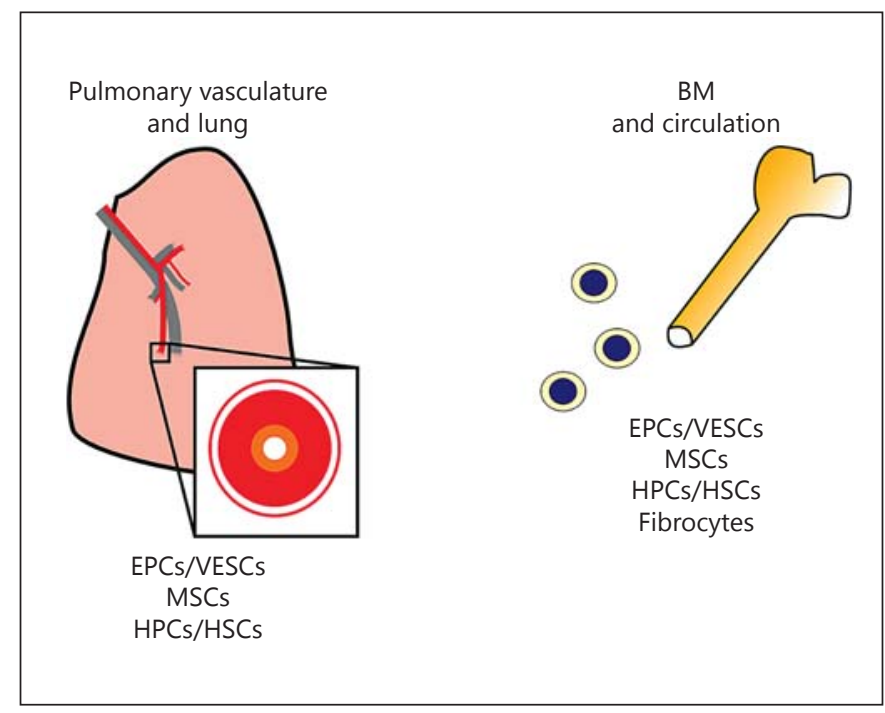

Fig. 1. Potential sources of stem and progenitor cells in the context of PAH. VESCs = Vascular endothelial stem cells.

world symposium on $\mathrm{PH}$ in Dana Point [2]. Idiopathic $\mathrm{PAH}$ (IPAH) is a subcategory of severe PAH without known cause of the disease [2]. Less than 20\% of IPAH patients and a large number of patients with hereditary $\mathrm{PAH}$ are heterogeneous for a mutation in bone morphogenic protein receptor 2 (BMPR2), a receptor of the transforming growth factor- $\beta$ family of receptors $[3,4]$. Despite decades of research, there is still no curative treatment for this crippling disease. Although several vasodilator treatments are currently available and are used regularly in clinical practice, these drugs do not seem to reduce the vascular occlusion, which is the main determinant of increased pulmonary vascular resistance $[1,5]$. Whereas previous pathobiological concepts have focused on the role of hypoxia and increased vasoconstriction, it is now accepted that postapoptotic overgrowth of phenotypically altered, hyperproliferative cells leads to the vascular obstruction $[1,6]$. For a detailed recent summary of the pathobiology of PAH please see the review by Rabinovitch [4]. Advanced severe PAH is characterized by socalled plexiform lesions, which are complex, multicellular vascular lesions $[7,8]$. Due to the lack of current curative treatment options for $\mathrm{PAH}$, it is instrumental that novel therapeutic approaches are developed which aim at restoring the vascular architecture of the lung.

In the recent years, our understanding of vascular development and vascular remodeling have increased significantly, in particular due to the advances made in the field of stem and progenitor cell research [9]. Stem cells are generally characterized by their undifferentiated state and their ability to produce progeny which is undergoing differentiation into specialized, terminally differentiated cells in order to replace other terminally differentiated cells that are lost, e.g. due to apoptosis [10]. This differentiated progeny is called progenitor cells, which often exhibit a high proliferation potential that is subsequently lost when progenitor cells undergo terminal differentiation [10]. A fraction of the stem cells maintains their undifferentiated, primitive state in so-called stem cell niches [10]. In the following paragraphs, we provide an overview over stem and progenitor cell populations with relevance for regenerative therapy in the context of pulmonary vascular disease (summary in fig. 1) and we extend our review on the published work that relates to the use of cells and factors for cell- and gene therapy-based approaches in the context of pulmonary vascular diseases (summary in fig. 2).

\section{Stem and Progenitor Cells and the Pulmonary Circulation}

\section{Circulating and Lung-Resident Endothelial Progenitor} and Stem Cells

Endothelial progenitor cells (EPCs) have been originally identified as circulating cells with pro-angiogenic properties which express markers of both progenitor cells and endothelial cells (ECs) and can be differentiated into ECs in vitro [11]. Various isolation techniques have yielded important subsets of cells: the EC colony-forming units (also early-outgrowth EPCs) and the EC colonyforming cells (also late-outgrowth EPCs). Whereas EC colony-forming units are more likely hematopoietic progenitors, can differentiate into macrophages, but lack the ability to establish functional vasculature, EC colonyforming cells have a higher proliferative potential and can form perfused vascular structures in vivo [12]. Circulating EPCs have been shown to be increased in IPAH, and EC colony-forming cells from PAH patients with BMPR2 mutations are hyperproliferative but impaired in their ability to form vascular tubes $[13,14]$.

EPCs resident in the vascular wall have been first shown in the arterial wall of the systemic circulation and may reside within the endothelium or at the border region between the tunica media and the tunica adventitia $[15,16]$. It is interesting that the arterial wall contains in fact a complete hierarchy of these EPCs [16]. These resident EPCs are characterized by a high proliferation po- 


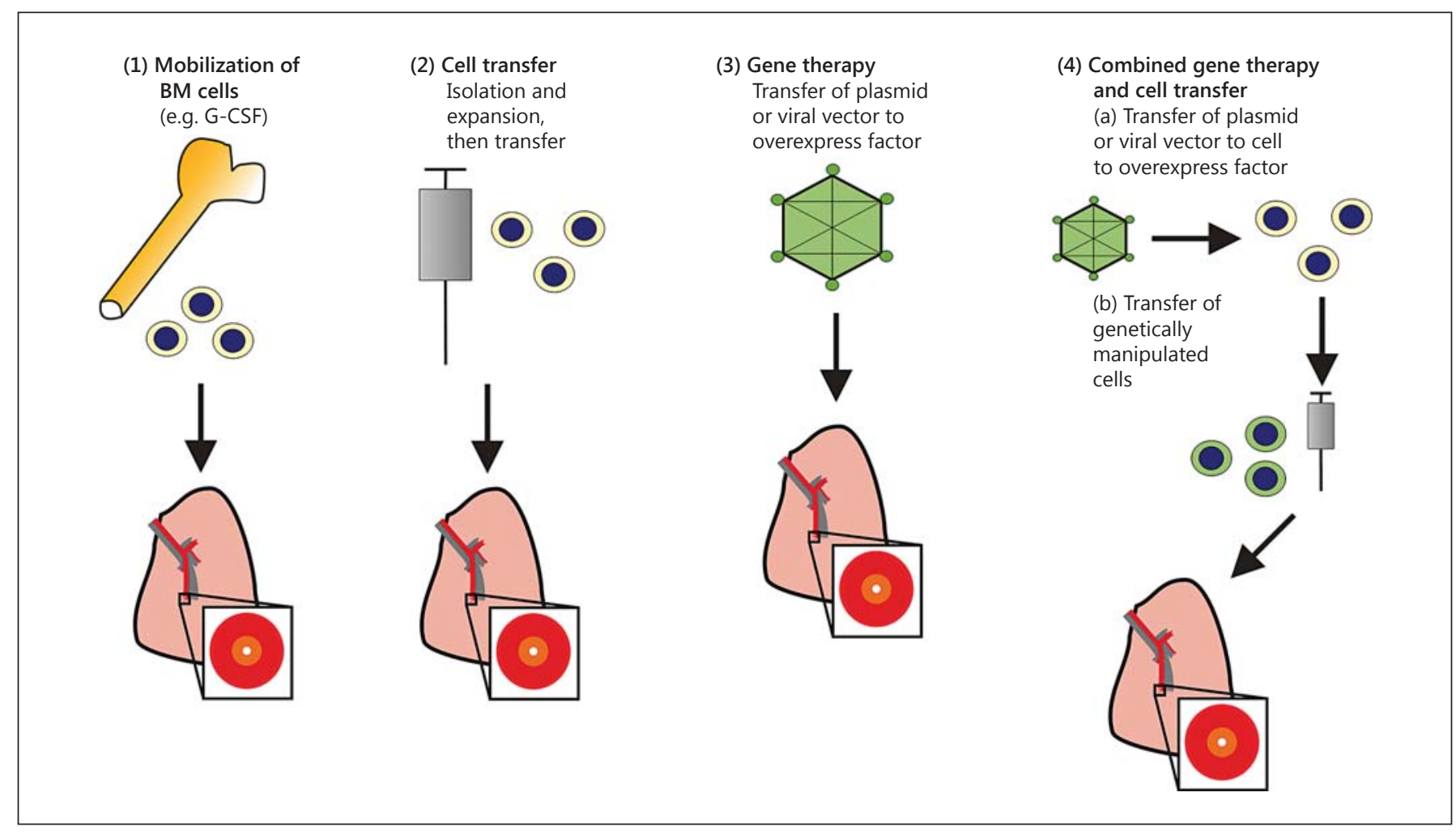

Fig. 2. Potential treatment strategies targeting vascular repair and regeneration in the context of PAH. Note that these strategies have been mainly studied in preclinical animal experiments. A detailed overview can be found in the main text. One common way to mobilize BM cells (1) is the intravenous injection of G-CSF. For cell transfer, cells are usually injected intravenously.

tential and the ability for clonal expansion [16]. In the lung vasculature, the microvascular pulmonary endothelium contains a high fraction of lung-resident EPCs which are responsible for the significant proliferation potential [17].

Recently, cells residing in human and murine lungs have been shown to be able to replace cells of the vascular wall: clonogenic human lung stem cells can regenerate all cells of the airways, vascular tree and alveolar wall when injected into the lungs of cryoinjured mice [18]. ECs isolated from the lungs of mice contain a population of vascular endothelial stem cells with a high proliferative capacity, clonal expansion potential and the ability to generate functional blood vessels [19]. The common denominator of both of these studies is the presence of stem cells with high proliferative and regenerative potential, which may serve as replacement pool for various cell types, including ECs, in the lung circulation.

\section{Lung-Resident and Bone Marrow-Derived Mesenchymal Stem Cells}

Mesenchymal stem cells (MSCs) have been originally identified in the bone marrow (BM) as plastic adherent, non-hematopoietic cells, which form fibroblast-like colonies, have a high proliferation potential and the ability to undergo differentiation into multiple mesenchymal and vascular lineages [20-22]. MSCs are also interesting for cellular therapeutic approaches because of their low immunogenic profile combined with anti-inflammatory properties [21, 23, 24]. In the BM, MSCs are important to maintain the integrity of the hematopoietic stem cell (HSC) niche and MSCs also regulate the trafficking of HSCs between BM, circulation and other organs [21]. MSCs themselves can also be mobilized from the BM and circulate to other organs in response to tissue injury [21]. The lung contains tissue-resident MSCs, and multipotent MSCs have been isolated from lung vascular lesions of patients with chronic thromboembolic PAH $[25,26]$. It is currently unclear whether lung-resident or BM-de- 
rived MSCs are part of the pathobiological process of lung vascular obliteration in $\mathrm{PAH}$, or are present in remodeled vessel walls in an attempt to repair the injured vessel wall.

\section{Hematopoietic Stem and Progenitor Cells}

HSCs and hematopoietic progenitor cells (HPCs) share a common developmental source with the ECs and are the common source for cells of the hematopoietic lineages $[27,28]$. HSCs reside in the BM in the so-called HSC niches, which are maintained by BM-resident MSCs [29]. In $\mathrm{PAH}$ patients, alterations in the $\mathrm{BM}$ composition and reticulin fibrosis were identified, suggesting a subclinical myeloproliferative process [30]. Putative HPCs have been shown in the arterial wall in the systemic circulation of mice and in pulmonary artery walls of chronic hypoxic mice $[31,32]$. Cells with a similar marker profile have also been identified in the plexiform lesion of patients with IPAH $[33,34]$. Transplantation of myeloid progenitors derived from human PAH patients, but not from healthy controls, to immunodeficient mice resulted in pulmonary vascular remodeling, in particular intravascular thrombosis [35]. These data indicate that BM-derived myeloid/hematopoietic progenitor/stem cells may contribute to the development of lung vascular lesions and PAH.

\section{Fibrocytes}

Fibrocytes are a subpopulation of circulating progenitor cells, which coexpress leukocyte, HPC and mesenchymal lineage markers, and have been mainly implicated in the course and prognosis of fibrotic disease, such as idiopathic pulmonary fibrosis [36-38]. It has been demonstrated that fibrocytes accumulate around the pulmonary arteries in chronic hypoxic mice, and that a prostacyclin analogue inhibits the recruitment of circulating fibrocytes to the lung vasculature of chronic hypoxic mice, which was associated with a slight reduction in lung vascular remodeling $[39,40]$. The biology of fibrocytes in the context of PAH has to be better understood before these cells may be considered for applications such as vehicle for gene therapy or drug delivery.

\section{Vascular Regeneration and Repair for PH}

Because of the concept of postapoptotic cell overgrowth as the underlying pathogenic problem in the pathobiology of $\mathrm{PAH}$, the administration of vasoprotective, pro-angiogenic factors would be expected to induce vascular regeneration and repair in the context of PAH. However, due to the nature of the complex vascular lesions, which are characterized by the presence of abnormal, hyperproliferative cells expressing EC markers, it is questionable whether simply boosting the angiogenic potential would in fact be beneficial or would actually promote disease progression. The choice of an appropriate model mimicking the human disease as closely as possible will be important to make valid preclinical decisions on the potential benefits of vascular regenerative therapy [41-44]. The most promising preclinical and clinical data are available for cell-based therapeutic approaches, where genetic manipulation, mostly of progenitor or stem cells, to overexpress a particular gene is combined with the transplantation of these modified cells. Such a cell transfer strategy may be useful for the treatment of a variety of lung diseases $[45,46]$. The concept behind this approach is that these cells will migrate to the remodeled vessels and will therefore deliver the gene product at the site of vascular injury. Whereas this concept is intriguing, it needs to be considered that our current knowledge regarding the true 'intentions' of these progenitor or stem cells accumulating in the lung vascular lesions is limited. Another important problem is the generation of cell cultures suitable for clinical application. A summary of potential strategies can be found in figure 2.

\section{Therapeutic Approaches Using Progenitor and Stem} Cells without Genetic Manipulation

The granulocyte colony-stimulating factor (G-CSF) is an important colony-stimulating factor that enhances neutrophil counts and neutrophil activity $[47,48]$. G-CSF has also been used to mobilize hematopoietic cells from the BM [49]. In a rat model, G-CSF reduced myocardial infarct size and the frequency of ventricular arrhythmias $[50,51]$. Whereas G-CSF administration in the monocrotaline (MCT) rat model of PAH resulted in improved survival and reduced PAH [52], G-CSF treatment worsened a-naphthylthiourea-induced $\mathrm{PH}$ [53], indicating a highly context-dependent effect of G-CSF treatment and BM cell mobilization.

The administration of more or less defined progenitor cell populations has been investigated, mainly in preclinical animal models, in the context of PAH. The concept underlying such an approach is based on the assumption that progenitor cells may help to repair the pulmonary vasculature. One frequently investigated cell population is constituted of BM-derived MSCs [23]. Several groups have shown that transplantation of BM-derived MSCs 
can reduce vascular remodeling and $\mathrm{PAH}$ in the MCT model [54-56], in a high flow-induced model of $\mathrm{PAH}$ [57, 58 ] and in a model of bronchopulmonary dysplasia and associated $\mathrm{PH}$ [59]. It is interesting that even intratracheal MSC administration results in reduced PAH in the MCT model [60]. In contrast, MSCs are not integrated in the pulmonary arteries of chronic hypoxic rats despite repeated infusions [61]. MSCs derived from human embryonic stem cells also reduce PAH in the MCT model of PAH according to a study by Zhang et al. [62].

$\mathrm{BM}$-derived mononuclear cells reduce canine MCTinduced PAH and these cells were detected in the endothelial layer of the lung vessels [63]. In another study by Spees et al. [64] using BM chimeric animals, BM-derived progenitor cells were detected in the lung of MCT rats as interstitial fibroblasts, myofibroblasts, hematopoietic cells, club cells (Clara), vascular ECs and smooth muscle cells, indicating that transplanted BM-derived cells may present with a rather heterogeneous phenotype in the lung.

EPCs have also been used in preclinical and early clinical studies for vascular regeneration in the context of $\mathrm{PAH}$ : canine and rodent MCT-induced PAH was reduced after the transplantation of blood- or BM-derived EPCs $[65,66]$. In contrast, human EC colony-forming units derived from the peripheral blood did not prevent or reduce mortality or vascular remodeling in MCT-induced PAH [67]. Wang et al. [68] have investigated the transplantation of autologous EPCs in a randomized controlled trial in IPAH patients and found an increase in the 6-min walk distance after 12 weeks.

CXC chemokine ligand 12 (CXCL12) belongs to the CXC family of chemokines, which contains four highly conserved cysteine residues, and the first two cysteine residues, separated by a variable amino acid, determine the name of this chemokine family [69]. CXCL12 (also known as stromal cell-derived factor $1 \alpha$ ) signals through CXC chemokine receptor 4 (CXCR4). CXCR4 signaling is not only important for chemotaxis and migration of circulating and resident cells towards a CXCL12 gradient but also for cell survival and proliferation [70]. Whereas activation of the CXCL12/CXCR4 axis has been shown to aid in the regeneration of the heart [71], elevated expression of CXCR4 and its ligand CXCL12 is found in plexiform lesions in PAH [14]. Indeed, CXCR4 inhibition resulted in reduced accumulation of putative HPCs and reduced vascular remodeling and $\mathrm{PAH}[31,72]$.

Overall, studies on BM-derived cell mobilization and migration show conflicting results, whereas a transfer of more selected cell populations such as MSCs or EPCs ap- pears to be more beneficial for the treatment of PAH. Carefully designed clinical evaluations need to provide substantial proof for the safety and efficacy of these treatment strategies before cell therapies should be considered as an established treatment option for PAH.

\section{Therapeutic Approaches Using Angiogenic Therapies} and Genetically Modified Cells

Vascular endothelial growth factor (VEGF) is a central angiogenic and growth factor that is highly expressed in the ECs of the lung vasculature. Inhibition of VEGF receptors induces EC apoptosis and severe obliterative $\mathrm{PAH}$ when combined with exposure to chronic hypoxia $[73,74]$. Although VEGF expression was found to be increased in human PAH lungs [75] and in lungs of chronic hypoxic rats [76,77], VEGF levels were reduced in the lungs of MCT rats [78] and in the lungs of chronic pulmonary diseases that are frequently associated with $\mathrm{PH}$, such as idiopathic pulmonary fibrosis $[79,80]$ and emphysema [81]. Gene therapeutic approaches with VEGF overexpression have been successful to reduce pulmonary vascular remodeling in the chronic hypoxia model of PAH [82], the MCT model of PAH [83] and our animal model of experimental lung fibrosis and associated PH [84]. One may suggest caution because VEGF overexpression could also promote the development of angio-obliterative angiogenic vasculopathy, as could be suggested by the finding of high levels of VEGF expression in plexiform lesions of $\mathrm{PAH}$ patients [75].

Endothelial nitric oxide synthase (eNOS) is important for the endothelial production of nitric oxide as a vasodilator targeting pulmonary artery smooth muscle cells [85]. The observation of decreased eNOS expression in pulmonary arteries of $\mathrm{PAH}$ patients and newborns with persistent $\mathrm{PH}$ provides a good rationale to attempt to increase eNOS expression as a treatment option [86, 87]. However, conflicting results have been published and indicate that eNOS may be increased in the lungs of PAH patients and chronic hypoxic rats [88, 89]. A study by Mason et al. [90] has provided a possible explanation for this controversy. The authors found that eNOS expression was reduced in small pulmonary arterioles of PAH patients, but eNOS was strongly expressed in the plexiform lesions of PAH patients. eNOS gene therapy has been demonstrated in several publications to be effective to treat PAH in animal models $[83,91,92]$. One mechanism may be the preservation of the microvascular architecture [92]. An early-phase clinical trial is investigating the tolerability of eNOS-enhanced autologous EPCs delivered into the pulmonary circulation of patients with 
severe PAH (the Pulmonary Hypertension and Cell Therapy trial, PHACeT; http://clinicaltrials.gov; identifier: NCT00469027). Results from two small clinical trials which examined the transplantation of autologous EPCs in patients with IPAH suggest that this approach may be safe and useful $[68,93]$. However, the long-term use of cell-based eNOS gene therapy may require careful evaluation, because enhancing eNOS levels or activation may potentially promote the progression of complex angiogenic lesions [94].

Prostacyclin $\left(\mathrm{PGI}_{2}\right)$ is the most important arachidonic acid metabolite of ECs and vascular smooth muscle cells, a powerful vasodilator and inhibitor of cell growth [95]. The expression of $\mathrm{PGI}_{2}$ synthase, the enzyme responsible for $\mathrm{PGI}_{2}$ biosynthesis, has been shown to be decreased in the pulmonary vasculature of IPAH patients [95]. Pulmonary overexpression of $\mathrm{PGI}_{2}$ synthase protects or reduces $\mathrm{PAH}$ in animal models $[96,97]$. Gene transfer of $\mathrm{PGI}_{2}$ synthase into skeletal muscles and the liver was also able to reduce $\mathrm{PAH}$ in rats $[98,99]$. The transplantation of MSCs transduced to overexpress $\mathrm{PGI}_{2}$ synthase reduced $\mathrm{PAH}$ and pulmonary vascular remodeling in MCT-treated rats [100].

Angiopoietins (Angs) represent a family of ligands for the Tie tyrosine kinase receptors Tie-1 and Tie-2, which are mostly found on ECs [101-104]. The well-investigated Angs are Ang-1 and Ang-2. Whereas Ang-1 is frequently produced by cells of the mesenchymal lineage, including smooth muscle cells, Ang-2 is mostly secreted by ECs [105-108]. Quiescent ECs produce very low levels of Ang-2, but activated ECs drastically increase their Ang-2 production [108-110]. Ang-2 can, depending on the angiogenic context, either promote angiogenesis or induce regression of vessels $[109,111]$. Two studies have yielded controversial results regarding the relevance of Ang-1 in PAH: whereas cell-based gene transfer of Ang-1 reduced PAH in the MCT model [112], Ang-1 overexpression in the lungs of healthy rats re- sulted in the development of PAH [113]. These data suggest a context-specific effect of Ang-1 on the pulmonary vasculature.

$B M P R 2$ loss of function is associated with mutations found in hereditary and sporadic severe PAH [4]. One possible strategy is gene transfer of wild-type BMPR2, which was successful in preclinical studies in chronic hypoxic rats and MCT-treated rats [114, 115]. A second potential strategy would be restoration of intracellular signaling of mutant BMPR2 [116].

\section{Conclusion and Perspective}

The pathobiology of PAH is complex and our current therapeutic approaches are not curative. Although there has been considerable progress in the understanding of the pathobiology of stem and progenitor cell biology as well as approaches targeting vascular repair and regeneration in the context of lung vascular remodeling and $\mathrm{PAH}$, there is considerable work to be done to understand the specific role of angiogenic factors and stem or progenitor cell populations in this complex disease. It is very likely that the curative treatment of severe PAH will require a multimodal approach that will utilize angiogenic vascular repair and stem/progenitor cell therapy. Because such therapies may also enhance the process of vascular remodeling, careful preclinical studies in models mimicking as many of the features of severe PAH as possible need to be conducted to rule out unwanted adverse effects.

\section{Acknowledgments}

Grant support by NIH/NHLBI grant HL114816 to L.F. and by a Canadian Institute for Health Research grant to M.K.

References

Erzurum S, Rounds SI, Stevens T, Aldred M, Aliotta J, Archer SL, Asosingh K, Balaban R, Bauer N, Bhattacharya J, Bogaard H, Choudhary G, Dorn GW II, Dweik R, Fagan K, Fallon M, Finkel T, Geraci M, Gladwin MT, Hassoun PM, Humbert M, Kaminski N, Kawut SM, Loscalzo J, McDonald D, McMurtry IF, Newman J, Nicolls M, Rabinovitch M, Shizuru J, Oka M, Polgar P, Rodman D, Schumacker P, Stenmark K, Tuder R, Voelkel N, Sullivan E, Weinshilboum R, Yoder MC, Zhao Y,
Gail D, Moore TM: Strategic plan for lung vascular research: an NHLBI-ORDR Workshop Report. Am J Respir Crit Care Med 2010; 182:1554-1562.

-2 Simonneau G, Robbins IM, Beghetti M, Channick RN, Delcroix M, Denton CP, Elliott CG, Gaine SP, Gladwin MT, Jing Z-C, Krowka MJ, Langleben D, Nakanishi N, Souza R: Updated clinical classification of pulmonary hypertension. J Am Coll Cardiol 2009;54:S43S54. 
- International PPH Consortium, Lane KB, 15 Zengin E, Chalajour F, Gehling UM, Ito WD, Machado RD, Pauciulo MW, Thomson JR, Phillips JA III, Loyd JE, Nichols WC, Trembath RC: Heterozygous germline mutations in BMPR2, encoding a TGF-beta receptor, cause familial primary pulmonary hypertension. Nat Genet 2000;26:81-84.

4 Rabinovitch M: Molecular pathogenesis of pulmonary arterial hypertension. J Clin Invest 2012;122:4306-4313.

5 Stacher E, Graham BB, Hunt JM, Gandjeva A, Groshong SD, McLaughlin VV, Jessup M, Grizzle WE, Aldred MA, Cool CD, Tuder RM: Modern age pathology of pulmonary arterial hypertension. Am J Respir Crit Care Med 2012;186:261-272.

-6 Sakao S, Tatsumi K, Voelkel NF: Reversible or irreversible remodeling in pulmonary arterial hypertension. Am J Respir Cell Mol Biol 2010; 43:629-634.

7 Cool CD, Stewart JS, Werahera P, Miller GJ, Williams RL, Voelkel NF, Tuder RM: Threedimensional reconstruction of pulmonary arteries in plexiform pulmonary hypertension using cell-specific markers. Evidence for a dynamic and heterogeneous process of pulmonary endothelial cell growth. Am J Pathol 1999; 155:411-419.

-8 Tuder RM, Abman SH, Braun T, Capron F, Stevens T, Thistlethwaite PA, Haworth SG: Development and pathology of pulmonary hypertension. J Am Coll Cardiol 2009;54:S3-S9.

-9 Kolios G, Moodley Y: Introduction to stem cells and regenerative medicine. Respiration 2013;85:3-10.

10 Weiss DJ, Bertoncello I, Borok Z, Kim C, Panoskaltsis-Mortari A, Reynolds S, Rojas M, Stripp B, Warburton D, Prockop DJ: Stem cells and cell therapies in lung biology and lung diseases. Proc Am Thorac Soc 2011;8: 223-272.

-11 Asahara T, Murohara T, Sullivan A, Silver M, van der Zee R, Li T, Witzenbichler B, Schatteman G, Isner JM: Isolation of putative progenitor endothelial cells for angiogenesis. Science 1997;275:964-967.

12 Yoder MC, Mead LE, Prater D, Krier TR, Mroueh KN, Li F, Krasich R, Temm CJ, Prchal JT, Ingram DA: Redefining endothelial progenitor cells via clonal analysis and hematopoietic stem/progenitor cell principals. Blood 2007;109:1801-1809.

-13 Asosingh K, Aldred MA, Vasanji A, Drazba J, Sharp J, Farver C, Comhair SAA, Xu W, Licina L, Huang L, Anand-Apte B, Yoder MC, Tuder RM, Erzurum SC: Circulating angiogenic precursors in idiopathic pulmonary arterial hypertension. Am J Pathol 2008;172: 615-627.

14 Toshner M, Voswinckel R, Southwood M, AlLamki R, Howard LSG, Marchesan D, Yang J, Suntharalingam J, Soon E, Exley A, Stewart S, Hecker M, Zhu Z, Gehling U, Seeger W, Pepke-Zaba J, Morrell NW: Evidence of dysfunction of endothelial progenitors in pulmonary arterial hypertension. Am J Respir Crit Care Med 2009;180:780-787.
Treede H, Lauke H, Weil J, Reichenspurner $\mathrm{H}$, Kilic N, Ergün S: Vascular wall resident progenitor cells: a source for postnatal vasculogenesis. Development 2006;133:1543-1551.

16 Ingram DA, Mead LE, Moore DB, Woodard W, Fenoglio A, Yoder MC: Vessel wall-derived endothelial cells rapidly proliferate because they contain a complete hierarchy of endothelial progenitor cells. Blood 2005; 105: 2783-2786.

17 Alvarez DF, Huang L, King JA, ElZarrad MK, Yoder MC, Stevens T: Lung microvascular endothelium is enriched with progenitor cells that exhibit vasculogenic capacity. Am J Physiol Lung Cell Mol Physiol 2008;294: L419-L430.

18 Kajstura J, Rota M, Hall SR, Hosoda T, D’Amario D, Sanada F, Zheng H, Ogórek B, Rondon-Clavo C, Ferreira-Martins J, Matsuda A, Arranto C, Goichberg P, Giordano G, Haley KJ, Bardelli S, Rayatzadeh H, Liu X, Quaini F, Liao R, Leri A, Perrella MA, Loscalzo J, Anversa P: Evidence for human lung stem cells. N Engl J Med 2011;364:1795-1806.

19 Fang S, Wei J, Pentinmikko N, Leinonen H, Salven P: Generation of functional blood vessels from a single c-kit+ adult vascular endothelial stem cell. PLoS Biol 2012;10:e1001407.

20 Pittenger MF, Mackay AM, Beck SC, Jaiswal RK, Douglas R, Mosca JD, Moorman MA, Simonetti DW, Craig S, Marshak DR: Multilineage potential of adult human mesenchymal stem cells. Science 1999;284:143-147.

21 Chamberlain G, Fox J, Ashton B, Middleton J: Concise review: mesenchymal stem cells: their phenotype, differentiation capacity, immunological features, and potential for homing. Stem Cells 2007;25:2739-2749.

-22 Bhatia R, Hare JM: Mesenchymal stem cells: future source for reparative medicine. Congest Heart Fail 2005;11:87-93.

23 Prockop DJ, Youn Oh J: Mesenchymal stem/ stromal cells (MSCs): role as guardians of inflammation. Mol Ther 2012;20:14-20.

24 Ntolios P, Janes SM: Mesenchymal stem cell therapy for lung diseases: oasis or mirage. Respiration 2013;85:279-280.

25 Lama VN, Smith L, Badri L, Flint A, Andrei A-C, Murray S, Wang Z, Liao H, Toews GB, Krebsbach PH, Peters-Golden M, Pinsky DJ, Martinez FJ, Thannickal VJ: Evidence for tissue-resident mesenchymal stem cells in human adult lung from studies of transplanted allografts. J Clin Invest 2007;117:989-996.

26 Firth AL, Yao W, Ogawa A, Madani MM, Lin GY, Yuan JX-J: Multipotent mesenchymal progenitor cells are present in endarterectomized tissues from patients with chronic thromboembolic pulmonary hypertension. Am J Physiol Cell Physiol 2010;298:C1217-C1225.

27 Loges S, Fehse B, Brockmann MA, Lamszus K, Butzal M, Guckenbiehl M, Schuch G, Ergün S, Fischer U, Zander AR, Hossfeld DK, Fiedler W, Gehling UM: Identification of the adult human hemangioblast. Stem Cells Dev 2004;13:229-242.
28 Prindull G: Hemangioblasts representing a functional endothelio-hematopoietic entity in ontogeny, postnatal life, and CML neovasculogenesis. Stem Cell Rev 2005;1:277-284.

29 Mendez-Ferrer S, Michurina TV, Ferraro F, Mazloom AR, MacArthur BD, Lira SA, Scadden DT, Ma'ayan A, Enikolopov GN, Frenette PS: Mesenchymal and haematopoietic stem cells form a unique bone marrow niche. $\mathrm{Na}$ ture 2010;466:829-834.

30 Farha S, Asosingh K, Xu W, Sharp J, George D, Comhair S, Park M, Tang WHW, Loyd JE, Theil K, Tubbs R, Hsi E, Lichtin A, Erzurum SC: Hypoxia-inducible factors in human pulmonary arterial hypertension: a link to the intrinsic myeloid abnormalities. Blood 2011; 117:3485-3493.

31 Gambaryan N, Perros F, Montani D, CohenKaminsky S, Mazmanian M, Renaud JF, Simonneau G, Lombet A, Humbert M: Targeting of c-kit+ haematopoietic progenitor cells prevents hypoxic pulmonary hypertension. Eur Respir J 2011;37:1392-1399.

32 Zengin E, Chalajour F, Gehling UM, Ito WD, Treede H, Lauke H, Weil J, Reichenspurner H, Kilic N, Ergun S: Vascular wall resident progenitor cells: a source for postnatal vasculogenesis. Development 2006;133:1543-1551.

33 Montani D, Perros F, Gambaryan N, Girerd B, Dorfmuller P, Price LC, Huertas A, Hammad H, Lambrecht B, Simonneau G, Launay J-M, Cohen-Kaminsky S, Humbert M: C-kitpositive cells accumulate in remodeled vessels of idiopathic pulmonary arterial hypertension. Am J Respir Crit Care Med 2011;184: 116-123.

34 Rai PR, Cool CD, King JAC, Stevens T, Burns N, Winn RA, Kasper M, Voelkel NF: The cancer paradigm of severe pulmonary arterial hypertension. Am J Respir Crit Care Med 2008; 178:558-564.

- 35 Asosingh K, Farha S, Lichtin A, Graham B, George D, Aldred M, Hazen SL, Loyd J, Tuder R, Erzurum SC: Pulmonary vascular disease in mice xenografted with human BM progenitors from patients with pulmonary arterial hypertension. Blood 2012;120:12181227.

36 Mehrad B, Burdick MD, Zisman DA, Keane MP, Belperio JA, Strieter RM: Circulating peripheral blood fibrocytes in human fibrotic interstitial lung disease. Biochem Biophys Res Commun 2007;353:104-108.

- 37 Moeller A, Gilpin SE, Ask K, Cox G, Cook D, Gauldie J, Margetts PJ, Farkas L, Dobranowski J, Boylan C, O’Byrne PM, Strieter RM, Kolb M: Circulating fibrocytes are an indicator of poor prognosis in idiopathic pulmonary fibrosis. Am J Respir Crit Care Med 2009;179:588-594.

-38 Phillips RJ, Burdick MD, Hong K, Lutz MA, Murray LA, Xue YY, Belperio JA, Keane MP, Strieter RM: Circulating fibrocytes traffic to the lungs in response to CXCL12 and mediate fibrosis. J Clin Invest 2004;114:438-446. 
- 39 Nikam VS, Schermuly RT, Dumitrascu R, Weissmann N, Kwapiszewska G, Morrell N, Klepetko W, Fink L, Seeger W, Voswinckel R: Treprostinil inhibits the recruitment of bone marrow-derived circulating fibrocytes in chronic hypoxic pulmonary hypertension. Eur Respir J 2010;36:1302-1314.

-40 Frid MG, Brunetti JA, Burke DL, Carpenter TC, Davie NJ, Reeves JT, Roedersheimer MT, van Rooijen N, Stenmark KR: Hypoxia-induced pulmonary vascular remodeling requires recruitment of circulating mesenchymal precursors of a monocyte/macrophage lineage. Am J Pathol 2006;168:659-669.

-41 Voelkel NF, Tuder RM: Hypoxia-induced pulmonary vascular remodeling: a model for what human disease? J Clin Invest 2000;106: 733-738.

42 Abe K, Toba M, Alzoubi A, Ito M, Fagan KA, Cool CD, Voelkel NF, McMurtry IF, Oka M: Formation of plexiform lesions in experimental severe pulmonary arterial hypertension. Circulation 2010;121:2747-2754.

-43 Gomez-Arroyo JG, Farkas L, Alhussaini AA Farkas D, Kraskauskas D, Voelkel NF, Bogaard HJ: The monocrotaline model of pulmonary hypertension in perspective. Am J Physiol Lung Cell Mol Physiol 2012;302: L363-L369.

44 Gomez-Arroyo JG, Saleem SJ, Mizuno S, Syded AA, Bogaard HJ, Abbate A, Taraseviciene-Stewart L, Sung Y, Kraskauskas D, Farkas D, Conrad DH, Nicolls MR, Voelkel NF: A brief overview of mouse models of pulmonary arterial hypertension: problems and prospects. Am J Physiol Lung Cell Mol Physiol 2012;302:L977-L991.

-45 Tzouvelekis A, Ntolios P, Bouros D: Stem cell treatment for chronic lung diseases. Respiration 2013;85:179-192.

-46 Bouros D, Laurent G: Regenerative medicine and stem cells: Prometheus revisited. Respiration 2013;85:1-2.

47 Furze RC, Rankin SM: Neutrophil mobilization and clearance in the bone marrow. Immunology 2008;125:281-288.

48 Azoulay E, Attalah H, Yang K, Jouault H, Schlemmer B, Brun-Buisson C, Brochard L, Harf A, Delclaux C: Exacerbation by granulocyte colony-stimulating factor of prior acute lung injury: implication of neutrophils. Crit Care Med 2002;30:2115-2122.

49 Greenbaum AM, Link DC: Mechanisms of GCSF-mediated hematopoietic stem and progenitor mobilization. Leukemia 2011;25:211217.

50 Baldo MP, Davel AP, Damas-Souza DM, Nicoletti-Carvalho JE, Bordin S, Carvalho HF, Rodrigues SL, Rossoni LV, Mill JG: The antiapoptotic effect of granulocyte colony-stimulating factor reduces infarct size and prevents heart failure development in rats. Cell Physiol Biochem 2011;28:33-40.
Baldo MP, Davel AP, Nicoletti-Carvalho JE, Bordin S, Rossoni LV, Mill JG: Granulocyte colony-stimulating factor reduces mortality by suppressing ventricular arrhythmias in acute phase of myocardial infarction in rats. J Cardiovasc Pharmacol 2008;52:375-380.

52 Maruyama H, Watanabe S, Kimura T, Liang J, Nagasawa T, Onodera M, Aonuma K, Yamaguchi I: Granulocyte colony-stimulating factor prevents progression of monocrotaline-induced pulmonary arterial hypertension in rats. Circ J 2007;71:138-143.

53 Azoulay E, Eddahibi S, Marcos E, Levame M, Harf A, Schlemmer B, Adnot S, Delclaux C: Granulocyte colony-stimulating factor enhances alpha-naphthylthiourea-induced pulmonary hypertension. J Appl Physiol 2003;94: 2027-2033.

54 Xie J, Hu D, Niu L, Qu S, Wang S, Liu S: Mesenchymal stem cells attenuate vascular remodeling in monocrotaline-induced pulmonary hypertension rats. J Huazhong Univ Sci Technolog Med Sci 2012;32:810-817.

55 Zhang ZH, Lu Y, Luan Y, Zhao JJ: Effect of bone marrow mesenchymal stem cells on experimental pulmonary arterial hypertension. Exp Ther Med 2012;4:839-843.

56 Jiang L, Song XH, Liu P, Zeng CL, Huang ZS, Zhu LJ, Jiang YZ, Ouyang HW, Hu H: Platelet-mediated mesenchymal stem cells homing to the lung reduces monocrotaline-induced rat pulmonary hypertension. Cell Transplant 2012;21:1463-1475.

57 Luan Y, Zhang X, Kong F, Cheng GH, Qi TG, Zhang ZH: Mesenchymal stem cell prevention of vascular remodeling in high flow-induced pulmonary hypertension through a paracrine mechanism. Int Immunopharmacol 2012;14:432-437.

58 Liu K, Liu R, Cao G, Sun H, Wang X, Wu S: Adipose-derived stromal cell autologous transplantation ameliorates pulmonary arterial hypertension induced by shunt flow in rat models. Stem Cells Dev 2011;20:10011010.

-59 Hansmann G, Fernandez-Gonzalez A, Aslam M, Vitali SH, Martin T, Mitsialis SA, Kourembanas S: Mesenchymal stem cell-mediated reversal of bronchopulmonary dysplasia and associated pulmonary hypertension. Pulm Circ 2012;2:170-181.

60 Baber SR, Deng W, Master RG, Bunnell BA, Taylor BK, Murthy SN, Hyman AL, Kadowitz PJ: Intratracheal mesenchymal stem cell administration attenuates monocrotaline-induced pulmonary hypertension and endothelial dysfunction. Am J Physiol Heart Circ Physiol 2007;292:H1120-H1128.

61 Rochefort GY, Vaudin P, Bonnet N, Pages JC, Domenech J, Charbord P, Eder V: Influence of hypoxia on the domiciliation of mesenchymal stem cells after infusion into rats: possibilities of targeting pulmonary artery remodeling via cells therapies? Respir Res 2005;6: 125.
62 Zhang Y, Liao S, Yang M, Liang X, Poon MW, Wong CY, Wang J, Zhou Z, Cheong SK, Lee $\mathrm{CN}$, Tse HF, Lian Q: Improved cell survival and paracrine capacity of human embryonic stem cell-derived mesenchymal stem cells promote therapeutic potential for pulmonary arterial hypertension. Cell Transplant 2012; 21:2225-2239.

63 Luan Y, Zhang ZH, Wei DE, Lu Y, Wang YB: Effects of autologous bone marrow mononuclear cells implantation in canine model of pulmonary hypertension. Circ J 2012;76:977985.

64 Spees JL, Whitney MJ, Sullivan DE, Lasky JA, Laboy M, Ylostalo J, Prockop DJ: Bone marrow progenitor cells contribute to repair and remodeling of the lung and heart in a rat model of progressive pulmonary hypertension. FASEB J 2008;22:1226-1236.

65 Takahashi M, Nakamura T, Toba T, Kajiwara N, Kato H, Shimizu Y: Transplantation of endothelial progenitor cells into the lung to alleviate pulmonary hypertension in dogs. Tissue Eng 2004;10:771-779.

-66 Sun CK, Lin YC, Yuen CM, Chua S, Chang LT, Sheu JJ, Lee FY, Fu M, Leu S, Yip HK: Enhanced protection against pulmonary hypertension with sildenafil and endothelial progenitor cell in rats. Int J Cardiol 2012;162: 45-58.

67 Mirsky R, Jahn S, Koskenvuo JW, Sievers RE, Yim SM, Ritner C, Bernstein HS, Angeli FS, Boyle AJ, De Marco T, Yeghiazarians Y: Treatment of pulmonary arterial hypertension with circulating angiogenic cells. Am J Physiol Lung Cell Mol Physiol 2011;301:L12L19.

68 Wang XX, Zhang FR, Shang YP, Zhu JH, Xie XD, Tao QM, Zhu JH, Chen JZ: Transplantation of autologous endothelial progenitor cells may be beneficial in patients with idiopathic pulmonary arterial hypertension: a pilot randomized controlled trial. J Am Coll Cardiol 2007;49:1566-1571.

69 Belperio JA, Keane MP, Arenberg DA, Addison CL, Ehlert JE, Burdick MD, Strieter RM: Cxc chemokines in angiogenesis. J Leukoc Biol 2000;68:1-8.

70 Domanska UM, Kruizinga RC, Nagengast WB, Timmer-Bosscha H, Huls G, de Vries EGE, Walenkamp AME: A review on CXCR4/ CXCL12 axis in oncology: no place to hide. Eur J Cancer 2013;49:219-230.

71 Askari AT, Unzek S, Popovic ZB, Goldman CK, Forudi F, Kiedrowski M, Rovner A, Ellis SG, Thomas JD, DiCorleto PE, Topol EJ, Penn MS: Effect of stromal-cell-derived factor 1 on stem-cell homing and tissue regeneration in ischaemic cardiomyopathy. Lancet 2003;362:697-703.

72 Yu L, Hales C: Effect of chemokine receptor CXCR4 on hypoxia-induced pulmonary hypertension and vascular remodeling in rats. Respir Res 2011;12:21. 
73 Kasahara Y, Tuder RM, Taraseviciene-Stewart L, Le Cras TD, Abman S, Hirth PK, Waltenberger J, Voelkel NF: Inhibition of VEGF receptors causes lung cell apoptosis and emphysema. J Clin Invest 2000;106: 1311-1319.

74 Taraseviciene-Stewart L, Kasahara Y, Alger L, Hirth P, Mc Mahon G, Waltenberger J, Voelkel NF, Tuder RM: Inhibition of the VEGF receptor 2 combined with chronic hypoxia causes cell death-dependent pulmonary endothelial cell proliferation and severe pulmonary hypertension. FASEB J 2001;15:427-438.

-75 Hirose S, Hosoda Y, Furuya S, Otsuki T, Ikeda E: Expression of vascular endothelial growth factor and its receptors correlates closely with formation of the plexiform lesion in human pulmonary hypertension. Pathol Int 2000;50: 472-479.

-76 Christou H, Yoshida A, Arthur V, Morita T, Kourembanas S: Increased vascular endothelial growth factor production in the lungs of rats with hypoxia-induced pulmonary hypertension. Am J Respir Cell Mol Biol 1998;18: 768-776.

-77 Tuder RM, Flook BE, Voelkel NF: Increased gene expression for VEGF and the VEGF receptors KDR/Flk and Flt in lungs exposed to acute or to chronic hypoxia. Modulation of gene expression by nitric oxide. J Clin Invest 1995;95:1798-1807.

-78 Arcot SS, Lipke DW, Gillespie MN, Olson JW: Alterations of growth factor transcripts in rat lungs during development of monocrotalineinduced pulmonary hypertension. Biochem Pharmacol 1993;46:1086-1091.

-79 Ebina M, Shimizukawa M, Shibata N, Kimura Y, Suzuki T, Endo M, Sasano H, Kondo T, Nukiwa T: Heterogeneous increase in CD34positive alveolar capillaries in idiopathic pulmonary fibrosis. Am J Respir Crit Care Med 2004;169:1203-1208.

80 Cosgrove GP, Brown KK, Schiemann WP, Serls AE, Parr JE, Geraci MW, Schwarz MI, Cool CD, Worthen GS: Pigment epitheliumderived factor in idiopathic pulmonary fibrosis: a role in aberrant angiogenesis. Am J Respir Crit Care Med 2004;170:242-251.

81 Kasahara Y, Tuder RM, Cool CD, Lynch DA, Flores SC, Voelkel NF: Endothelial cell death and decreased expression of vascular endothelial growth factor and vascular endothelial growth factor receptor 2 in emphysema. Am J Respir Crit Care Med 2001;163:737-744.

-82 Partovian C, Adnot S, Raffestin B, Louzier V, Levame M, Mavier IM, Lemarchand P, Eddahibi S: Adenovirus-mediated lung vascular endothelial growth factor overexpression protects against hypoxic pulmonary hypertension in rats. Am J Respir Cell Mol Biol 2000;23:762-771.

83 Zhao YD, Courtman DW, Ng DS, Robb MJ, Deng YP, Trogadis J, Han RN, Stewart DJ: Microvascular regeneration in established pulmonary hypertension by angiogenic gene transfer. Am J Respir Cell Mol Biol 2006;35: 182-189.
84 Farkas L, Farkas D, Ask K, Möller A, Gauldie J, Margetts P, Inman M, Kolb M: VEGF ameliorates pulmonary hypertension through inhibition of endothelial apoptosis in experimental lung fibrosis in rats. J Clin Invest 2009; 119:1298-1311.

85 Palmer RM, Ferrige AG, Moncada S: Nitric oxide release accounts for the biological activity of endothelium-derived relaxing factor. Nature 1987;327:524-526.

86 Giaid A, Saleh D: Reduced expression of endothelial nitric oxide synthase in the lungs of patients with pulmonary hypertension. $\mathrm{N}$ Engl J Med 1995;333:214-221.

87 Villanueva MET, Zaher FM, Svinarich DM, Konduri GG: Decreased gene expression of endothelial nitric oxide synthase in newborns with persistent pulmonary hypertension. Pediatr Res 1998;44:338-343.

88 Xue C, Johns RA: Endothelial nitric oxide synthase in the lungs of patients with pulmonary hypertension. N Engl J Med 1995;333: 1642-1644.

89 Le Cras TD, Xue C, Rengasamy A, Johns RA: Chronic hypoxia upregulates endothelial and inducible no synthase gene and protein expression in rat lung. Am J Physiol 1996; 270:L164-L170.

90 Mason NA, Springall DR, Burke M, Pollock J, Mikhail G, Yacoub MH, Polak JM: High expression of endothelial nitric oxide synthase in plexiform lesions of pulmonary hypertension. J Pathol 1998;185:313-318.

91 Champion HC, Bivalacqua TJ, Greenberg SS, Giles TD, Hyman AL, Kadowitz PJ: Adenoviral gene transfer of endothelial nitric-oxide synthase (eNOS) partially restores normal pulmonary arterial pressure in eNOS-deficient mice. Proc Natl Acad Sci USA 2002;99: 13248-13253.

92 Zhao YD, Courtman DW, Deng Y, Kugathasan L, Zhang Q, Stewart DJ: Rescue of monocrotaline-induced pulmonary arterial hypertension using bone marrow-derived endothelial-like progenitor cells: efficacy of combined cell and eNOS gene therapy in established disease. Circ Res 2005;96:442-450.

-93 Zhu JH, Wang XX, Zhang FR, Shang YP, Tao QM, Zhu JH, Chen JZ: Safety and efficacy of autologous endothelial progenitor cells transplantation in children with idiopathic pulmonary arterial hypertension: open-label pilot study. Pediatr Transplantat 2008;12: 650-655.

94 Zhao Y-Y, Zhao YD, Mirza MK, Huang JH, Potula H-HSK, Vogel SM, Brovkovych V, Yuan JXJ, Wharton J, Malik AB: Persistent eNOS activation secondary to caveolin-1 deficiency induces pulmonary hypertension in mice and humans through PKG nitration. J Clin Invest 2009;119:2009-2018.

95 Tuder RM, Cool CD, Geraci MW, Wang J, Abman SH, Wright L, Badesch D, Voelkel NF: Prostacyclin synthase expression is decreased in lungs from patients with severe pulmonary hypertension. Am J Respir Crit Care Med 1999;159:1925-1932.
$\$ 96$ Geraci MW, Gao B, Shepherd DC, Moore MD, Westcott JY, Fagan KA, Alger LA, Tuder RM, Voelkel NF: Pulmonary prostacyclin synthase overexpression in transgenic mice protects against development of hypoxic pulmonary hypertension. J Clin Invest 1999;103:1509-1515.

97 Nagaya N, Yokoyama C, Kyotani S, Shimonishi M, Morishita R, Uematsu M, Nishikimi T, Nakanishi N, Ogihara T, Yamagishi M, Miyatake K, Kaneda Y, Tanabe T: Gene transfer of human prostacyclin synthase ameliorates monocrotaline-induced pulmonary hypertension in rats. Circulation 2000; 102:2005-2010.

98 Suhara H, Sawa Y, Fukushima N, Kagisaki K, Yokoyama C, Tanabe T, Ohtake S, Matsuda $\mathrm{H}$ : Gene transfer of human prostacyclin synthase into the liver is effective for the treatment of pulmonary hypertension in rats. J Thorac Cardiovasc Surg 2002;123:855-861.

-99 Tahara N, Kai H, Niiyama H, Mori T, Sugi Y, Takayama N, Yasukawa H, Numaguchi Y, Matsui H, Okumura K, Imaizumi T: Repeated gene transfer of naked prostacyclin synthase plasmid into skeletal muscles attenuates monocrotaline-induced pulmonary hypertension and prolongs survival in rats. Hum Gene Ther 2004;15:1270-1278.

100 Takemiya K, Kai H, Yasukawa H, Tahara N, Kato S, Imaizumi T: Mesenchymal stem cellbased prostacyclin synthase gene therapy for pulmonary hypertension rats. Basic Res Cardiol 2010;105:409-417.

101 Partanen J, Armstrong E, Makela TP, Korhonen J, Sandberg M, Renkonen R, Knuutila S, Huebner K, Alitalo K: A novel endothelial cell surface receptor tyrosine kinase with extracellular epidermal growth factor homology domains. Mol Cell Biol 1992;12: 1698-1707.

102 Iwama A, Hamaguchi I, Hashiyama M, Murayama Y, Yasunaga $\mathrm{K}$, Suda T: Molecular cloning and characterization of mouse TIE and TEK receptor tyrosine kinase genes and their expression in hematopoietic stem cells. Biochem Biophys Res Commun 1993;195: 301-309.

103 Sato TN, Qin Y, Kozak CA, Audus KL: Tie-1 and tie-2 define another class of putative receptor tyrosine kinase genes expressed in early embryonic vascular system. Proc Natl Acad Sci USA 1993;90:9355-9358.

104 Schnurch H, Risau W: Expression of tie-2, a member of a novel family of receptor tyrosine kinases, in the endothelial cell lineage. Development 1993;119:957-968.

105 Davis S, Aldrich TH, Jones PF, Acheson A, Compton DL, Jain V, Ryan TE, Bruno J, Radziejewski C, Maisonpierre PC, Yancopoulos GD: Isolation of angiopoietin-1, a ligand for the TIE2 receptor, by secretiontrap expression cloning. Cell 1996;87:11611169. 
106 Stratmann A, Risau W, Plate KH: Cell typespecific expression of angiopoietin-1 and angiopoietin-2 suggests a role in glioblastoma angiogenesis. Am J Pathol 1998;153: 1459-1466.

107 Sugimachi K, Tanaka S, Taguchi K, Aishima S, Shimada M, Tsuneyoshi M: Angiopoietin switching regulates angiogenesis and progression of human hepatocellular carcinoma. J Clin Pathol 2003;56:854-860.

108 Hegen A, Koidl S, Weindel K, Marme D, Augustin $\mathrm{HG}$, Fiedler U: Expression of angiopoietin-2 in endothelial cells is controlled by positive and negative regulatory promoter elements. Arterioscler Thromb Vasc Biol 2004;24:1803-1809.

109 Fiedler U, Augustin HG: Angiopoietins: a link between angiogenesis and inflammation. Trends Immunol 2006;27:552-558.
110 Oh H, Takagi H, Suzuma K, Otani A, Matsumura M, Honda Y: Hypoxia and vascular endothelial growth factor selectively up-regulate angiopoietin-2 in bovine microvascular endothelial cells. J Biol Chem 1999;274: 15732-15739.

111 Lobov IB, Brooks PC, Lang RA: Angiopoietin-2 displays VEGF-dependent modulation of capillary structure and endothelial cell survival in vivo. Proc Natl Acad Sci USA 2002;99:11205-11210.

112 Zhao YD, Campbell AI, Robb M, Ng D, Stewart DJ: Protective role of angiopoietin-1 in experimental pulmonary hypertension. Circ Res 2003;92:984-991.

113 Sullivan CC, Du L, Chu D, Cho AJ, Kido M, Wolf PL, Jamieson SW, Thistlethwaite PA: Induction of pulmonary hypertension by an angiopoietin 1/TIE2/serotonin pathway. Proc Natl Acad Sci USA 2003; 100:1233112336.
14 Reynolds AM, Xia W, Holmes MD, Hodge SJ, Danilov S, Curiel DT, Morrell NW, Reynolds PN: Bone morphogenetic protein type 2 receptor gene therapy attenuates hypoxic pulmonary hypertension. Am J Physiol Lung Cell Mol Physiol 2007;292:L1182L1192.

115 Reynolds AM, Holmes MD, Danilov SM, Reynolds PN: Targeted gene delivery of BMPR2 attenuates pulmonary hypertension. Eur Respir J 2012;39:329-343.

16 Yang J, Davies RJ, Southwood M, Long L, Yang X, Sobolewski A, Upton PD, Trembath RC, Morrell NW: Mutations in bone morphogenetic protein type II receptor cause dysregulation of Id gene expression in pulmonary artery smooth muscle cells: implications for familial pulmonary arterial hypertension. Circ Res 2008;102:1212-1221. 